\title{
実験用口蓋床に付着するプラークの経時的変化について
}

\author{
名原 行徳 安部倉 仁 玉本 光弘 \\ 前谷 照男 浜田 泰三
}

\section{Change of Plaque Accumulation on Experimental Palatal Plate}

\author{
Yukinori Nahara, Hitoshi Abekura, Mitsuhiro Tamamoto, \\ Teruo Maetani and Taizo Hamada
}

\begin{abstract}
I. 緒言
近年，補緅臨床においても，プラークに代表される補 緅物表面に付着・蓄積寸る不潔な沈着物が，5蝕や歯周 疾患, 粘膜の炎症 ${ }^{129}$ などに少なからず関与しているこ とや, 補緅物そのものの物性を劣化させることから補緅 物に対するプラーク コントロールの重要性が提唱され ている ${ }^{10,11)}$.

しかし、プラークの付着・蓄積は, 被付着物質, 付着 部位, 微生物, 唾液, 食物の性状など数多くの要因に影 響され，複雑なプラーク形成過程をたどるものと考えら れる(12).

そこで，今回われわれは，被付着物質として義歯を想 定し, 義歯床口蓋粘膜面に付着・蓄積するプラークの発 生部位，広がりを知る目的で，実験用口蓋床を作製しこ の床に付着・蓄積するプラークを経時的に観察した.
\end{abstract}

\section{II. 実験材料ならびに方法}

\section{1. 被験者}

被験者は, 歯・歯周組織に異常がなく, 正常歯列を有 寸る成人男女 12 名（男性 7 名，女性 5 名，年齢 $18 \sim 31$ 歳)とした.

\section{2. 実験用口蓋床}

実験用口蓋床 (以後, 口蓋床と略す) は, 精密印象

広島大学歯学部歯科補緅学第二講座 (主任 : 浜田泰三教授) Department of Prosthetic Dentistry, Hiroshima University School of Dentistry (Chief : Prof. Taizo Hamada) 昭和 59 年 7 月 2 日受付
材 (パイエル日本歯科, デリクロン)にて, 被験者上䫑 の精密印象を行い，作業模型上で作製した (図 1)、口蓋 床前縁㧍よび側縁は歯列口蓋側歯頸部に接し，後縁は第 2 大曰歯遠心端を連ねた線に設定，歯冠部を歯頸部より $1 \mathrm{~mm}$ 上方で切断した後, 28 番のシートワックスを口蓋 部に圧接した．つぎに超硬石こうにてコアを採得，流蠟 後, 流し込みレジン(ニッシン社製, Poly Base Q) を, シリンジにて注入し, 加圧重合器を用いて $50^{\circ} \mathrm{C}, 1.5$ 気 圧，20 分間重合を行い，口蓋床を作製した. 口蓋床は, 各被鉴者につき， 7 個ずつ作製し， 6 個はプラークの付 着部位・広がりの実験に，1個は走查型電子顕微鏡の試 料に供した.

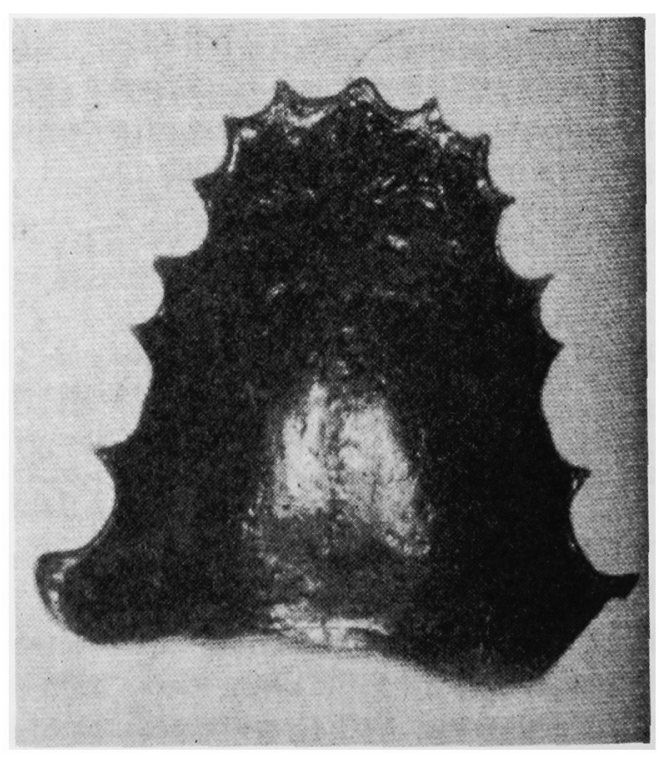

図 1 実験用口蓋床（流しこみレジン） 


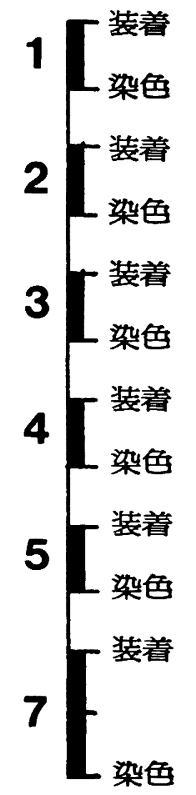

図 2 実験用口蓋床の装着期間 (黒太線) 各装着期間の間は 1 日休止した（数字は，日数を示す）

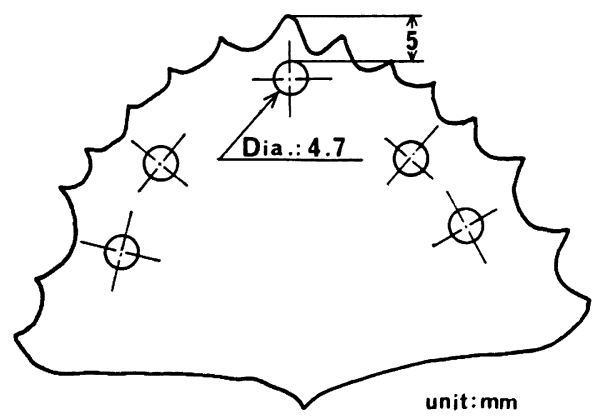

图 3 実験用口蓋床における走査型電子顕微鏡試料採取の 位置と大きさ

\section{3. 実験方法}

A. プラークの口蓋床粘膜面への付着と広がりの観察 被験者に，口蓋床を $1,2 ， 3 ４, 5 ， 7$ 日間装着させた 後, 取り出し, 流水中にて軽く水洗の後, $4 \%$ メチン ブルーで染色し, 水洗, 乾燥を行った (図 2). つぎに, 薄いピニールシートを口蓋床粘膜面に圧接し, その上に 染色された部位のトレースを行うことで，プラーク付着 の経時的広がりを観察した。

B. 口蓋床粘膜面に付着したプラークの走査型電子顕 微鏡による観察

中切歯中央, 左右第 1 小臼歯，左右第 1 大臼歯の歯頸 部から, $5 \mathrm{~mm}$ の所に直径 $4.7 \mathrm{~mm}$ の小孔を設け, 即時
重合レジンを筆積み法にて築盛, 走査型電子顕微鏡の試 料に供した（図 3). この試料は, 装着後, $1,2,4,8,12$ 時間，1，2，3，5，7 日後に取り出し，直ちに水洗し，2.5\% グルタルアルデヒドで固定の後, 通法に従い, 脱水, 乾 燥を行った.つぎに, 真空蒸着装置 (エイコー社製, IB-3 型）にて，金蒸着を行い，走査型電子顕微鏡（日立電子 社製，S-430）にて観察を行った.

\section{III. 実験結果}

\section{1. プラークのロ蓋床粘膜面への付着と広がり}

図 4-A，B は，プラークの口蓋床への付着の広がって 行く様子をトレースしたものである. 図 4-A は, プラ 一ク付着が口蓋床前縁および側縁から始まった例を示し ている. プラーク付着は, 数時間後より始まり， 2 日目 から 3 日目にかけて増加を示し，口蓋床前縁および側縁 から中央部へと広がりを示した。 写真上で観察を行う と, 濃染部は最初, 口蓋床前縁および側縁部に沿って広 がりを示すが， 5 日目以後あまり変化は認められなかっ た. 図 4-B は, プラーク付着が口蓋床後縁から始まった 例を示し, 数時間後より口蓋床後縁部からプラーク付着 が始まり， 口蓋床前縁および側縁部へと広がりを示し た. 4 日目以後，あまり変化が認められなかった．写真 上で観察を行うと濃染部は，2 日目に口蓋床後縁で認め られ，3 日目以後，口蓋床前縁および側縁周縁部へと広 がり，以後，あまり変化が認められなかった．つぎに， 図 5 のグラフは, 口蓋床に付着したプラークの付着面積 を\% (百分率) で示したものである. 左のグラフは, プ ラーク付着の少なかった例を示し，1日目 $10 \% ， 2$ 日目 から 3 日目にかけて $25 \%$ 一と増加，7日目には $40 \%$ を 認めた. 右のグラフは，プラーク付着の多かった例を示 し， 1 日目 $10 \% ， 2$ 日目 $25 \% ， 3$ 日目 $75 \% ， 5$ 日目 $95 \%$ となり，7日目ではあまり変化が認められなかった.こ れらより 2 日目から 3 日目にかけて, プラーク付着の急 激な増加を認めた。

\section{2. 走査型電子顕微鏡の観察結果}

図 6-A は，1，2，4，8，12 時間後の口蓋床粘膜面のレジ ン試料の走査型電子顕微鏡写真である. 1 2 時間後で は, 細菌の付着は認められず, 食物残渣や剝雇上皮と思 われるものが付着していた. 4 時間後では, 表面を薄膜 が覆いその上に球菌が散在していた. 8 時間, 12 時間後 でも同様な像を認めた. 図 6-B は，1，2，3，5，7 日後の 走查型電子顕微鏡写真である. 1 日後では, 細菌が集落 

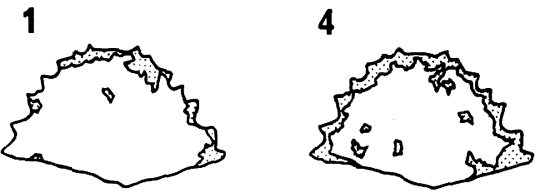

2

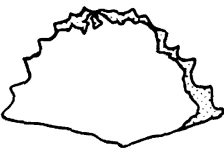

3

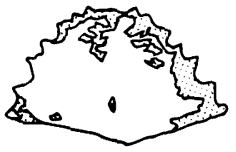

5

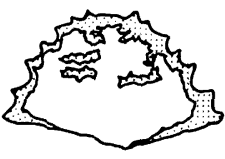

7

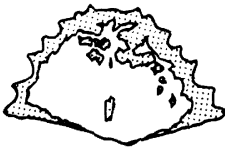

図 4-A プラーク付着が口蓋床前縁および側縁部から 始まった例

（被験者 No. 2)（数字は日数在示寸）
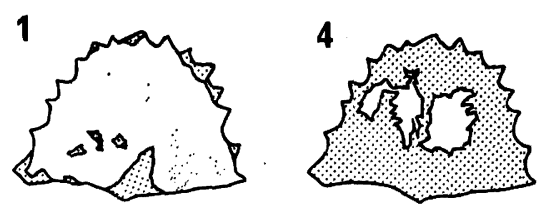

2
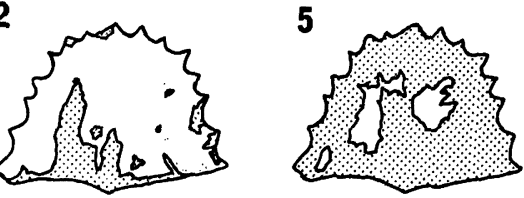

3

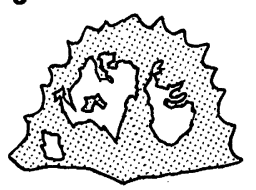

7

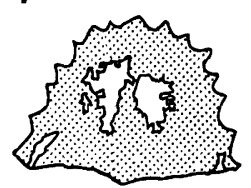

図 4-B プラ゙ーク付着が口蓋床後縁部から始まった例 （被験者 No. 5）（数字は日数を示す）
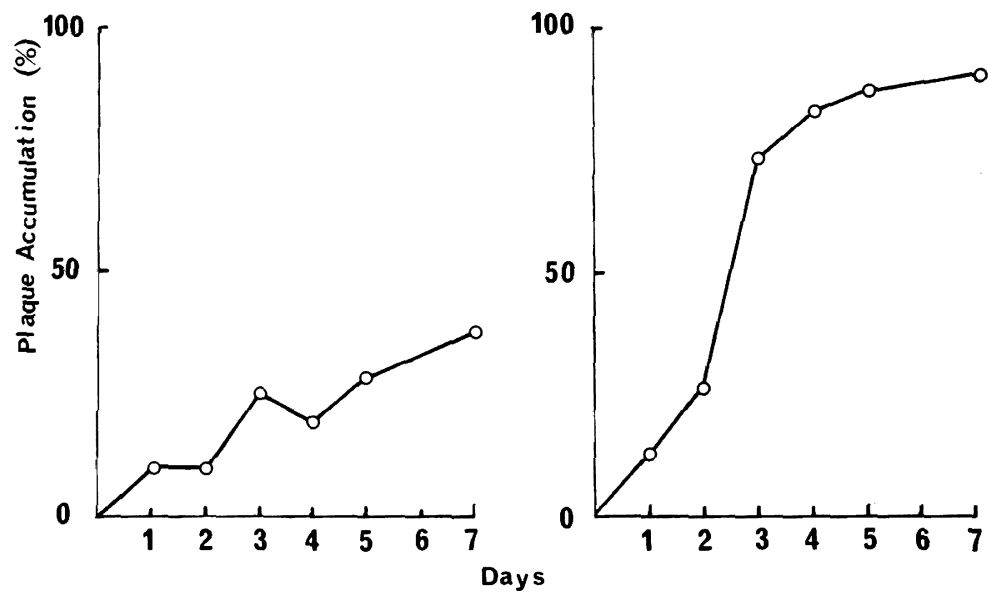

図 5 プラーク付着面稍の経時的変化

左のグラフ：プラーク付着の少なかった例（被験者 No. 7)

右のグラフ：プラーク付着の多かった例（被験者 No. 10）

縦軸：口蓋床面積を $100 \%$ として，プラーク付着面積を\%表示した

横軸：口蓋床装着日数

をなしているものが散在し，3 日後では細菌が層をな し，その上を皮膜で覆われ，細菌の形状が明瞭に認めら れなかった. 5 日後, 7 日後では, さらに層が厚くなり, その上に球菌などの散在している像を認めた。 なお, 本 研究では 7 日間の観察期間中, 真菌は認めなかった。 ま た，観察期間中，床下粘膜に発赤などの変化は認めなか
った.

IV. 考察

義歯装着患者において床下粘膜部に炎症が認められ， その原因は義歯粘膜面に付着する Candida albicans で 

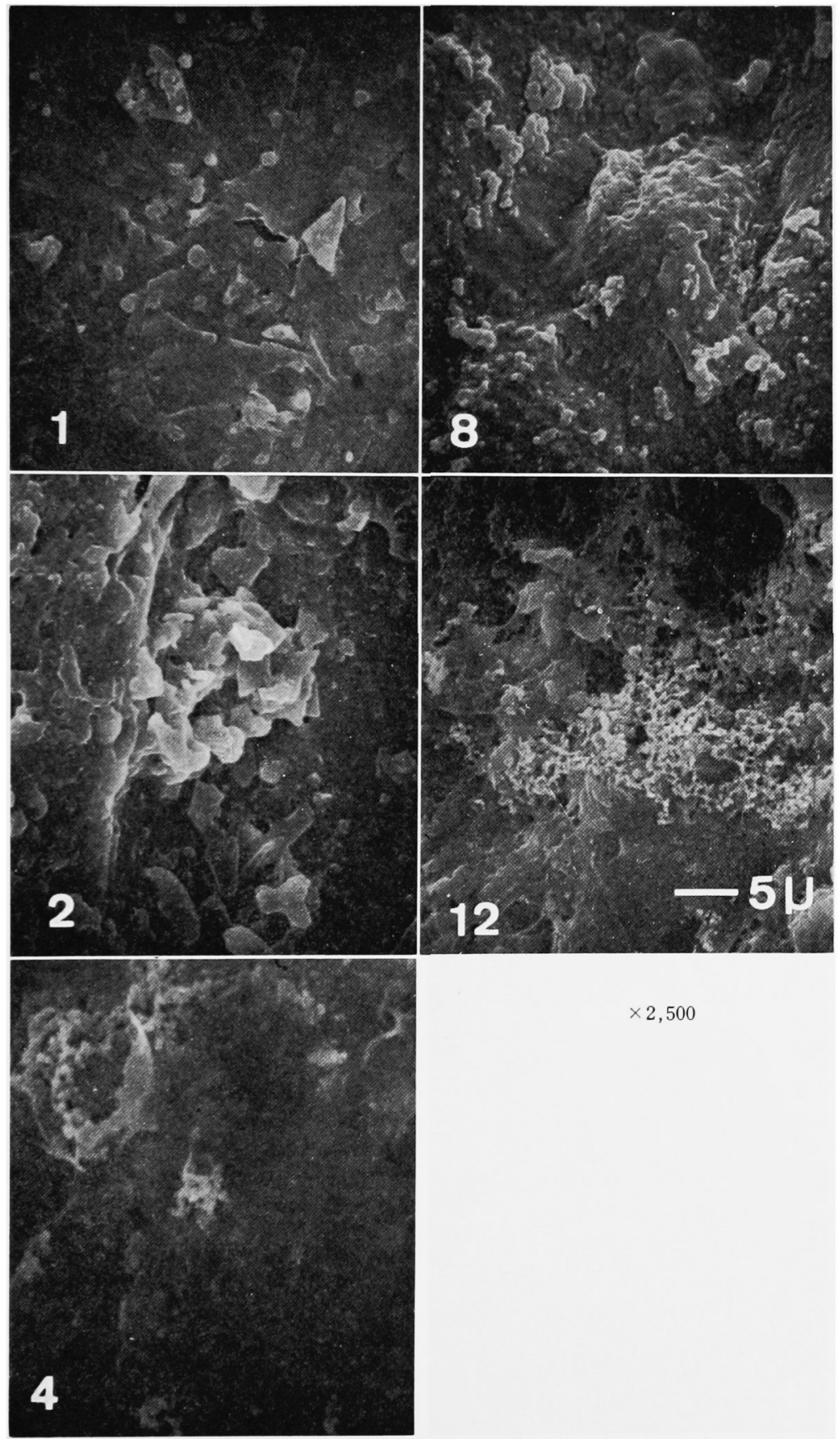

$\times 2,500$

図 6-A 口蓋床の大臼歯付近における $1,2,4,8,12$ 時間後の試料粘膜面の走查型電子顕微鏡写真

あるといわれている，それは, Candida が粘膜上皮表面 の酵素破壊や遅延型過敏反応などによって病的反応を引 き起こしているためと考えられ，部位は上顎義歯全体で あったり，義歯床前縁および側縁部や口蓋すう壁部，歯
槽頂部付近, 義歯床後縁部に限局されたものも認められ $ろ^{13)}$.

本実験においては, プラーク付着に関し, 口蓋床後縁 部から始まるものと, 口蓋床前縁および側縁部から始ま 

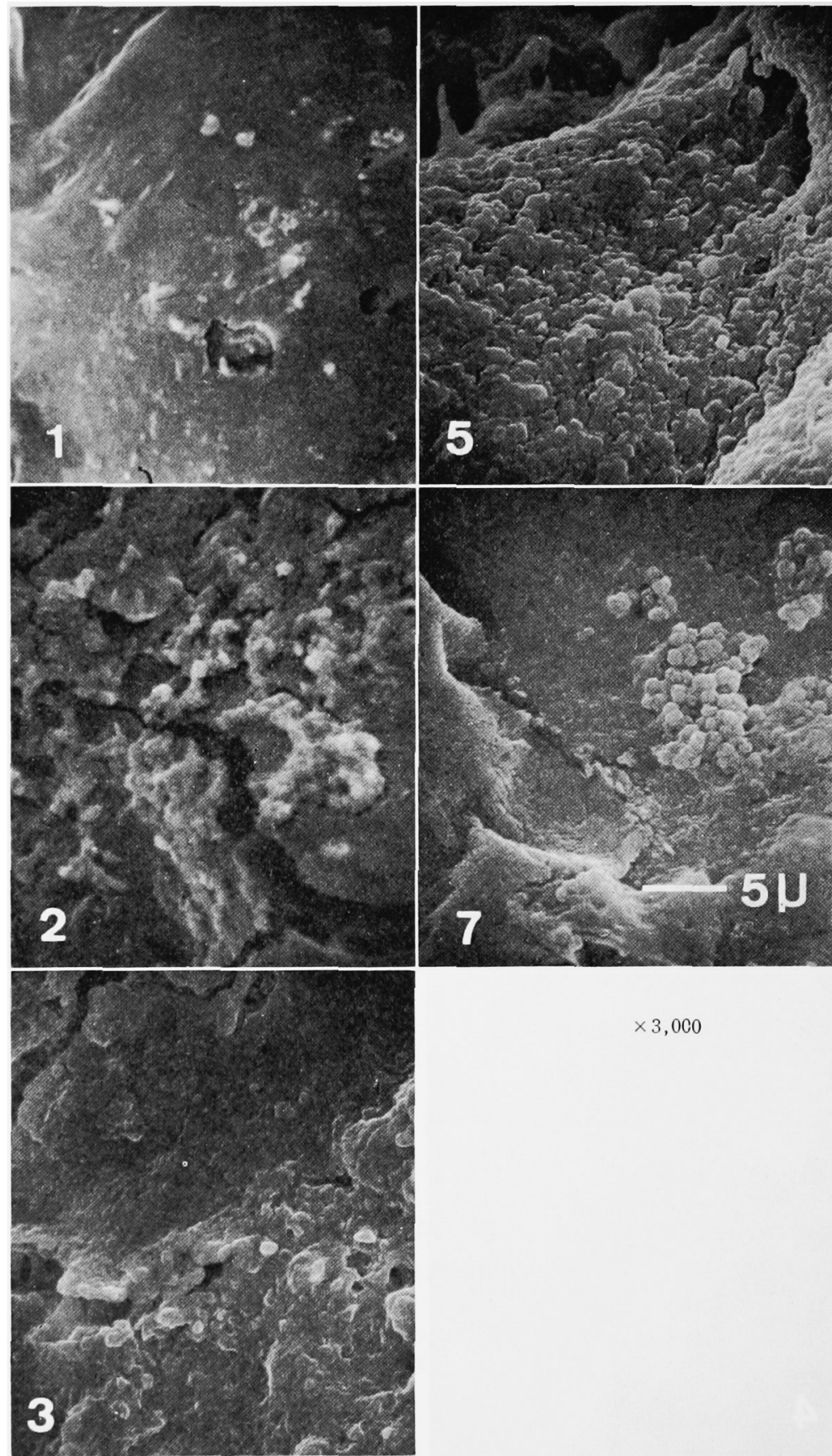

$\times 3,0 \mathrm{CO}$

図 6-B 口笽床の大曰歯付近における $1 ， 2 ， 3 ， 5 ， 7$ 日後の試料粘膜面の走查型電子顕微鏡写真

るものでは, $3: 1$ の割合で口蓋床後縁部から始まるもの の方が多かった。 しかし， 口蓋床と義歯床では維持や辺 縁封鎖性に違いがあり，様相は異なるものと考えられ る.義歯床では，口蓋床よりも床前縁および側縁の設定
不良や，口唇，煩粘膜の働きにより食渣や睡液の圧入が 容易之考えられる，床後縁部では，口蓋床でも義歯床で も同様に，印象時の唾液の流出や，硬・軟口蓋移行部の ため印象による十分な封鎖がなされないため，床前縁お 
よび側縁部よりもさらにプラークが付着しやすいものと 考えられる．プラークは，口蓋床後縁や前縁および側縁 部から食渣や唾液が入りこみ, Denture Pellicle を形成, その上に口腔常在菌などが付着し広がっていくものと考 えられる. また，義歯床粘膜面のアンダーカット部，レ ジンの気泡，口蓋すう壁部などもプラークが付着しやす く，これらを起始点として，プラーク付着が増加するも のと考えられる.

本研究では，口蓋床粘膜面に形成されたプラークの動 態は，伊良原ら ${ }^{12)}$ と同様であるが，初期過程を詳しく観 察すると， 4 時間後には，球菌の付着を認め, 同時に剝 離上皮や有機皮膜も認められた. なお，保存修復用レジ ンに対するプラーク付着の観察においても類似の傾向が 報告されている14)，1 日後では，散在した球菌の集落を 認め，2 日後では，急激に集落が増加し，桿菌や系状菌 も認められた. 3 日後では，菌の形状が明瞭に認められ なくなり層をなしていた，7日後では，試料面全体に細 菌が層をなし，有機皮膜で覆われ，さらにその上に，球 菌などの付着を認めた.

このように, プラーク付着の広がりに関しては, 義歯 床の辺縁封鎖性や，細菌層の動きが，重要な因子となっ ているものと考えられる15 18).

\section{V. 結 論}

本実験では，口蓋床に付着するプラークの発生部位， その広がりについて検討を行った。

1）プラークは，口蓋床後縁や前縁および側縁部より 付着し，中央部への広がりを示した。

2）プラークは，口蓋すう壁部や，レジンの気泡，ア ンダーカットとなる部位に認められた。

3） 口蓋床に付着するプラークは, 数時間で Denture Pellicle を形成し，2〜3 日目にかけて急激なプラーク付 着の増加を認めた。

本研究より，床下粘膜面のプラークの広がりという観 点からは，義歯床後縁，前縁および側縁部はできるだけ 完全に封鎖することが望ましい，そして，レジン床に対 しては，口腔内装着数時間後にはプラークが付着する事 実から，患者に対しては，初期の段階から義歯の取り扱 いや清掃することの重要性を指遒し，デンチャー プラ ーク コントロールを徹底させることが重要である.

本研究の一部は文部省科学研究費（昭和 59 年度奖励研究 A5977・1457）によった。
文献

1）中村治郎，山崎敬介：歯冠補緅物と歯周疾患との関係につ いて, 日保誌, $4: 104 \sim 109,1981$.

2) Löe, $\mathrm{H}:$ Reaction of marginal periodontal tissue to restorative procedure, Int. Dent. J., $18: 759 \sim 778$, 1967.

3) Silness, J. : Periodontal condition in Patients treated with dental bridge, J. Periodont. Res., $5: 60 \sim 68,219$ $\sim 224,1970$.

4) Bergman, B., Hugoson, A. and Olsson, C.O. : Periodontal and prosthetic conditions in patients treated with removal partial dentures and artificial crowns, Acta Odont. Scand., 29:621 638, 1972.

5) Schwartz, M.L. and Phillip, R. W. : Comparison of Bacterial accumulation on rough and smooth enamel surfaces, J. Periodont., 28 : 304 307, 1957.

6）村上繁樹，内田康也，浦郷篤史：歯冠補释物が歯牙・歯周 組織に及ぼす影響について一剖検顎骨の病理組織学的研究 一, 補緅誌, $22: 650 \sim 663,1978$.

7）三代幸彦：歯垢の成因, 歯界展望, $40: 733 \sim 737,1973$.

8）高添一郎：歯垢と口腔疾患, 歯界展望, $40: 748 \sim 751$, 1973.

9）原沢正昭，神谷洋行，浦田淑子，丸山栄子，神田敬子，原 耕二 : プラーク付着の歯肉組織への影響に関する臨床的研 究, 日歯周誌, $23(2): 327 \sim 338,1981$.

10）大西正男：歯垢による疾患子防，歯界展望，40：752 756, 1973.

11）石川 純, 片山 剛, 池田雅彦：プラークコントロールの 意義とその効果, 歯科評論, $370: 1 \sim 9,1973$.

12）伊良原彰, 石原 修, 三木敬一, 池田雅彦, 石川 純, 星 野 洸：義歯床粘膜面のプラーク形成について，北海道歯 科医師学会誌, $30: 56 \sim 59,1975$.

13）浜田泰三：デンチャー プラーク コントロール，永末書 店, $1 \sim 9,1983$

14）林原久盛, 蓝 瑞香, 村上潡子, 山根いうみ, 香西淑子, 佐藤尚毅, 新谷英章, 井上時雄 : 保存修復材への口腔内細 菌の初期付着について (in vivo)，広大蔽誌，15：115〜 118,1983

15）池田雅彦, 片山 剛, 石川 純, 星野 洸：口腔内に拈け る初期歯垢の形成について, 北海道歯科医師学会誌, 29 : $17 \sim 21,1974$

16）嶋倉道郎：橋義歯ポンティック基底面に付着するプラーク の観察一プラークの性状と粘膜に及ぼす影響一, 補緅誌, $20: 171 \sim 187,1976$.

17) Millin, D.J. and Smith, M.J. : Nature and composition of dental plaque, Nature, (Lond.), 189, 644 655, 1961.

18) Smith, M.H. : Amino acid analysis of denture pellicle and a glycoprotain containing component of saliva, J. Dent. Res. 43, 302, 1964. 